\title{
C-Reactive Protein Induces Interleukin-6 and Thrombospondin-1 Protein and mRNA Expression through Activation of Nuclear Factor- $k B$ in HK-2 Cells
}

\author{
Hai-rong Wang ${ }^{a}$ De-liang Chen ${ }^{a}$ Mingming Zhao ${ }^{a}$ Shao-wu Shu ${ }^{b}$ \\ Shi-xi Xiong ${ }^{a}$ Xue-dong Gan ${ }^{a}$ Sheng-ping Chao ${ }^{a}$ Jian-lei Cao ${ }^{a}$ \\ ${ }^{a}$ Department of Cardiology, Zhongnan Hospital of Wuhan University, and b State Key Laboratory of Freshwater \\ Ecology and Biotechnology, Wuhan, People's Republic of China
}

\section{Key Words}

C-reactive protein - Renal tubular epithelial cells ·

Mitogen-activated protein kinase $\cdot$ Nuclear factor-kappa B . Interleukin-6 $\cdot$ Thrombospondin-1

\begin{abstract}
Background: Although C-reactive protein (CRP) is significantly increased in patients with diabetic nephropathy, whether CRP exerts direct proinflammatory effects on human renal tubular epithelial cells (HK-2 cells) is still unclear. Methods: HK-2 cells were incubated with purified CRP at clinically relevant concentrations $(0,5,10,20$ and $40 \mu \mathrm{g} / \mathrm{ml})$. The protein and transcript levels of thrombospondin-1 (TSP-1) and interleukin- 6 (IL-6) were determined by ELISA and RTPCR. Phosphorylation of p38MAPK was investigated through Western blot analysis in HK-2 cells induced by CRP. The activation of nuclear factor-kappa B (NF-кB) was studied via EMSA. A specific p38MAPK inhibitor (SB203580) and an NF- $\kappa$ B inhibitor (PDTC; pyrrolidine dithiocarbamate) were used to analyze the signal transduction in CRP induction. To explore the direct or indirect role of CRP in HK-2 cells, IL- 6 or TSP-1 antibodies were used. The expression of IL-6, TSP-1 and transforming growth factor- $\beta_{1}$ (TGF- $\left.\beta_{1}\right)$ were determined through Western blot analysis in HK-2 cells. Results: In HK-2 cells, puri-
\end{abstract}

fied CRP significantly induced protein release and mRNA expression of IL- 6 and TSP-1 in a dose- and time-dependent manner. TGF- $\beta_{1}$ protein was overexpressed in HK-2 cells induced by CRP, which cannot be inhibited by IL- 6 or TSP- 1 antibodies. CRP triggered phosphorylation of p38MAPK and activation of NF-KB-mediated signal transduction. SB203580 $(5 \mu \mathrm{M})$ and PDTC $(50 \mu \mathrm{M})$ efficiently suppressed those effects of CRP in HK-2 cells. Conclusions: CRP induces IL- 6 and TSP-1 protein release and $m R N A$ expression from HK-2 cells via activation of the p38MAPK and NF- $\mathrm{kB}$ signaling pathways and TGF- $\beta_{1}$ was highly expressed in HK-2 cells, suggesting that CRP plays an important role in the propagation and prolongation of inflammation in renal fibrosis.

Copyright $\odot 2012$ S. Karger AG, Basel

\section{Introduction}

Serum hs C-reactive protein (CRP) levels are significantly increased in type 2 diabetes mellitus patients with renal insufficiency [1], which suggests that inflammatory cytokines are activated in the late stages of the patho-

H. Wang and D. Chen contributed equally to this paper.

\section{KARGER}

Fax +4161306 1234 E-Mail karger@karger.ch www.karger.com
(C) 2012 S. Karger AG, Basel

1420-4096/12/0354-0211\$38.00/0

Accessible online at:

www.karger.com $/ \mathrm{kbr}$
Hai-rong Wang

Department of Cardiology

Zhongnan Hospital of Wuhan University

169 Dong Hu Road, Wuhan 430071 (People's Republic of China)

Tel. +86 276781 3073, E-Mail wanghai2192@sina.com 
physiologic process that underlies diabetes and that these cytokines contribute to a considerable degree to renal dysfunction $[2,3]$. CRP has been proposed to be an independent risk factor for atherosclerosis [4-7]. Several studies have shown that CRP has direct proinflammatory effects on vascular cells, such as activation of the classical complement pathway, induction of adhesion molecules, and inhibition of nitric oxide production [8-11]. However, the molecular effect of CRP on human kidney tubular epithelial cells (HK-2 cells) during the inflammatory processes remains to be explored.

Tubular epithelial cells are now believed to play a major role in the progression and maintenance of tubulointerstitial fibrosis. Tubular epithelial cells can undergo a phenotypic change towards a myofibroblast-like phenotype, which indicates that transdifferentiation of tubular epithelial cells plays a role in progressive renal fibrosis in human glomerulonephritis [12].

Thrombospondin-1 (TSP-1) and interleukin-6 (IL-6) play a critical role in the development of renal tubulointerstitial fibrosis $[13,14]$. The present study was undertaken to investigate the effect of CRP on the secretion of IL- 6 and TSP-1 using HK-2 cells. The underlying intracellular signal transduction pathways were also investigated.

\section{Materials and Methods}

\section{Purification of CRP}

CRP (human) was obtained from American Sigma (St. Louis, Mo., USA) and purified (to remove possible biological contaminants, such as sodium azide and LPS) as described previously [15]. The content of LPS in the purified CRP solutions (5, 10, 20 and 40 $\mu \mathrm{g} / \mathrm{ml}$ ) was found to be $<5 \mathrm{pg} / \mathrm{ml}$, as determined using Limulus endotoxin assays. The purity of CRP preparations was determined using $12.5 \%$ sodium dodecyl sulfate-polyacrylamide gel electrophoresis (SDS-PAGE). A 25-kDa single band corresponding to CRP was observed after staining gels with sensitive silver staining. In brief, CRP was filtered with Amicon-Ultra 4 (10,000 molecular weight cut off; Millipore Corporation, Bedford, Mass. USA) at $4^{\circ} \mathrm{C}$ and then washed twice with $20 \mathrm{ml}$ of $0.9 \% \mathrm{NaCl}$ solution in an intravenous solution (Otsuka, Tokushima, Japan). After CRP had been washed, its concentrations were measured using a commercial enzyme-linked immunosorbent assay (ELISA) kit specific for human CRP (Alpha Diagnostic International, Tex., USA). In some experiments, the purified CRP was immunoprecipitated with anti-CRP antibody (Dako Cytomation, Denmark) or nonimmune control IgG (Dako Cytomation), followed by a 16hour incubation of protein $\mathrm{G}$ agarose (Santa Cruz Biotechnology, Inc.). The immunoprecipitated proteins were separated by centrifugation, and supernatants were collected for cell stimulation. Experiments were performed with the purified CRP, unless stated otherwise.

\section{Cell Culture}

HK-2 cells were obtained from the American Type Culture Collection and maintained in Opti-MEM-I medium (Gibco BRL) supplemented with $10 \%$ fetal bovine serum and $2 \mathrm{mM}$ glutamine. HK-2 cells were used at passage 3 or 4 in all the experiments.

Stimulation of HK-2 Cells with CRP

Before stimulation with the purified CRP or PBS, HK-2 cells $\left(2 \times 10^{6}\right.$ cells $/ 6-\mathrm{cm}$ dish $)$ were starved for $24 \mathrm{~h}$ with serum-free Opti-MEM-I medium. HK-2 cells were treated with various concentrations $(0,5,10,20$ and $40 \mu \mathrm{g} / \mathrm{ml})$ of the purified CRP for $24 \mathrm{~h}$. HK-2 cells were pretreated with SB203580 (5 $\mu \mathrm{M})$ or pyrrolidine dithiocarbamate (PDTC) $(50 \mu \mathrm{M})$ for 60 min separately and then stimulated with CRP $(20 \mu \mathrm{g} / \mathrm{ml})$. Following treatment, IL-6 and TSP-1 levels in the culture media were analyzed via RT-PCR and ELISA.

ELISA Analysis for IL-6 and TSP-1

The levels of IL- 6 and TSP-1 in cultured supernatants were determined using a commercial ELISA kit specific for human IL-6 (R\&D Systems, Minneapolis, Minn., USA) and TSP-1 (ADL systems) according to the manufacturers' recommendations. These assays employ the quantitative sandwich enzyme immunoassay techniques using a rat monoclonal antibody against murine IL-6 or TSP-1 polyclonal secondary antibody conjugated with horseradish peroxidase. All experiments were performed in triplicate.

\section{RT-PCR for IL-6 mRNA and TSP-1 mRNA Expression}

RNA was isolated and purified using an RNeasy Mini Kit (Qiagen) according to the manufacturer's protocol. The primers used were: IL-6 - sense: 5'-GGAGACGCCTTGAAGTAACTGC3', antisense: 5'-GAGTTTCCTCTGACTCCATCGCAG-3'. TSP1 - sense 5'-AAAGCGTCTTCACCAGAGACC-3', antisense: 5'GCAGATGGTAACTGAGTTCTGACA-3'.

PCR assays for IL- 6 were performed with a thermal cycler protocol of $50^{\circ} \mathrm{C}$ for $2 \mathrm{~min}$ before the first cycle, then $95^{\circ} \mathrm{C}$ for $15 \mathrm{~s}$, and $60^{\circ} \mathrm{C}$ for $1 \mathrm{~min}$, with this cycle repeated 45 times. PCR for TSP-1 was carried out with a thermal cycler protocol of $94^{\circ} \mathrm{C}$ for $3 \mathrm{~min}$ before the first cycle, then $94^{\circ} \mathrm{C}$ for $60 \mathrm{~s}$ and $55^{\circ} \mathrm{C}$ for $60 \mathrm{~s}$, with this cycle repeated 35 times. For PCR amplification assays, GAPDH was used as a control [16].

Western Blot Analysis of TSP-1, IL-6, Transforming Growth

Factor- $\beta_{1}\left(T G F-\beta_{1}\right)$ and Phosphorylated-p38MAPK

HK-2 cells $\left(2 \times 10^{6}\right.$ cells $\left./ \mathrm{ml}\right)$ cultured in $6-\mathrm{cm}$ dishes for $24 \mathrm{~h}$ were washed with Opti-MEM-I medium and then treated with different doses of CRP $(5,10,20$ and $40 \mu \mathrm{g} / \mathrm{ml})$ for $20 \mathrm{~h}$. The collected culture cells were then analyzed for TSP-1, IL- 6 and p38MAPK levels via Western blot analysis.

Preparation of supernatant samples and Western blot analyses were performed as described previously $[17,18]$. Briefly, cell lysates $(50 \mu \mathrm{g})$ obtained from CRP-treated HK-2 cells samples $(40 \mu \mathrm{l}) \mathrm{ex}-$ tracted from heparin beads were subjected to $12 \%$ SDS-PAGE, and the separated proteins were then transferred onto a nitrocellulose membrane (Amersham Biosciences). The membrane was blocked with $5 \%$ nonfat dry milk in Tris-buffered saline ( $\mathrm{pH} 7.4)$ containing $0.02 \%$ Tween 20 (TBST) for $1 \mathrm{~h}$ at room temperature and then incubated with an anti-TSP-1 antibody $(2 \mu \mathrm{g} / \mathrm{ml})$, anti-IL- 6 antibody $(2 \mu \mathrm{g} / \mathrm{ml})$, anti-TGF- $\beta_{1}$ antibody $(2 \mu \mathrm{g} / \mathrm{ml})$ or an anti-p38MAPK 


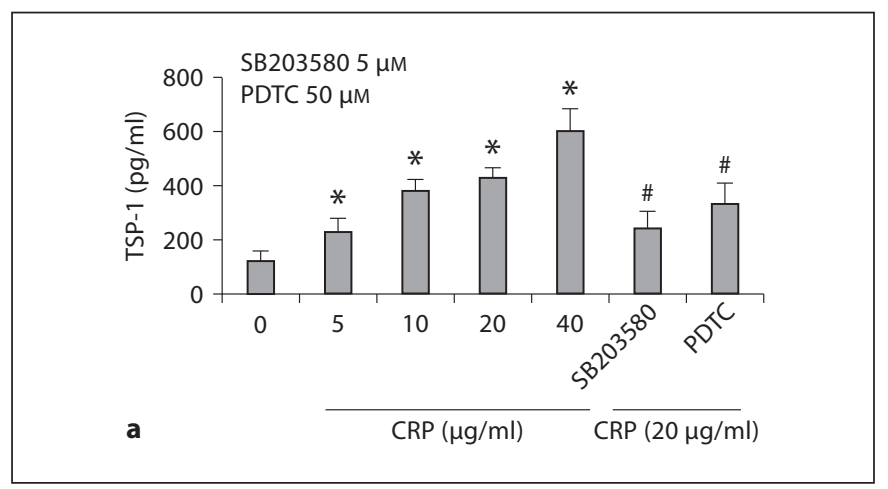

Fig. 1. Dose- and time-dependent effect of CRP on TSP-1 and IL-6 release in HK-2 cells. A specific inhibitor of p38MAPK (SB203580) and a specific inhibitor of NF- $\mathrm{B}$ (PDTC) significantly suppressed CRP-induced IL- 6 and TSP-1 release. a Dose-dependent effect of CRP and PDTC or SB203580 intervention on TSP-1 release in HK-2 cells. b Dose-dependent effect of CRP and PDTC or SB203580 intervention on IL-6 release in HK-2 cells. c Time-dependent effect of CRP on TSP-1 and IL- 6 release in HK-2 cells. ${ }^{*} \mathrm{p}<0.01$ versus the negative control group; ${ }^{\#} \mathrm{p}<0.01$ versus the CRP $(20 \mu \mathrm{g} / \mathrm{ml})$ group.

antibody $(2 \mu \mathrm{g} / \mathrm{ml})$ separately in TBST containing $1 \%$ nonfat dry milk for $3 \mathrm{~h}$ at room temperature. The membrane was then washed and incubated with a horseradish-peroxidase-conjugated anti-rabbit IgG polyclonal antibody (Santa Cruz) diluted 1:3,000 in TBST containing $2.5 \%$ nonfat dry milk for $1 \mathrm{~h}$ at room temperature. The membrane was then washed a second time, and immunoreactive bands were visualized using an ECL detection system.

\section{Electrophoretic Mobility Shift Assay (EMSA) for Nuclear}

Factor-Kappa-B (NF- $\kappa B)$ Activation

An EMSA test kit was obtained from Promega. Nuclear extracts from HK-2 cells were prepared according to the method of Beg et al. [19]. Binding reactions were performed in a $20-\mu l$ volume containing $4 \mu \mathrm{g}$ of nuclear protein extracts, $10 \mathrm{mM}$ Tris-Cl $(\mathrm{pH} 7.5), 50 \mathrm{~mm} \mathrm{NaCl}, 1 \mathrm{~mm}$ EDTA, $0.1 \mathrm{~mm}$ dithiothreitol, $10 \%$ glycerol, $2 \mu \mathrm{g}$ of poly(dI-dC) (nonspecific competitor), and $40,000 \mathrm{cpm}$ of ${ }^{32} \mathrm{P}$-labeled specific oligonucleotide probe. Doublestranded oligonucleotides containing the consensus sequence of the binding site for transcription factor NF- $\mathrm{B}$ (5'-AGTTGAGGGGACTTTCCCAGG-3') were purchased from Promega and labeled with $\left[\gamma^{-32} \mathrm{P}\right]$-ATP (Amersham Pharmacia) using T4 polynucleotide kinase. Binding reactions were performed at $37^{\circ} \mathrm{C}$ for $30 \mathrm{~min}$ in 30 $\mu \mathrm{l}$ of reaction buffer containing $10 \mathrm{mM}$ Tris- $\mathrm{HCl}(\mathrm{pH}$ 7.5), $100 \mathrm{mM}$ $\mathrm{NaCl}, 1 \mathrm{~mm}$ EDTA, 4\% glycerol, $1 \mu \mathrm{g}$ of poly(dI-dC), and $1 \mathrm{~mm}$ DTT. DNA-protein complexes were separated from the unbound DNA probe on native $5 \%$ polyacrylamide gels at $100 \mathrm{~V}$ in $0.5 \times$ TBE buffer. The gels were then dried and exposed to X-ray film at $-70^{\circ} \mathrm{C}$ for $24 \mathrm{~h}$. The intensity of the bands corresponding to specific NF- $\kappa$ B-DNA binding was determined via laser scanning (Typhoon 9200 type, Sweden) with gel Imagequant software.

CRP Induces HK-2 Cells to Release Cytokines via NF- $\mathrm{B}$
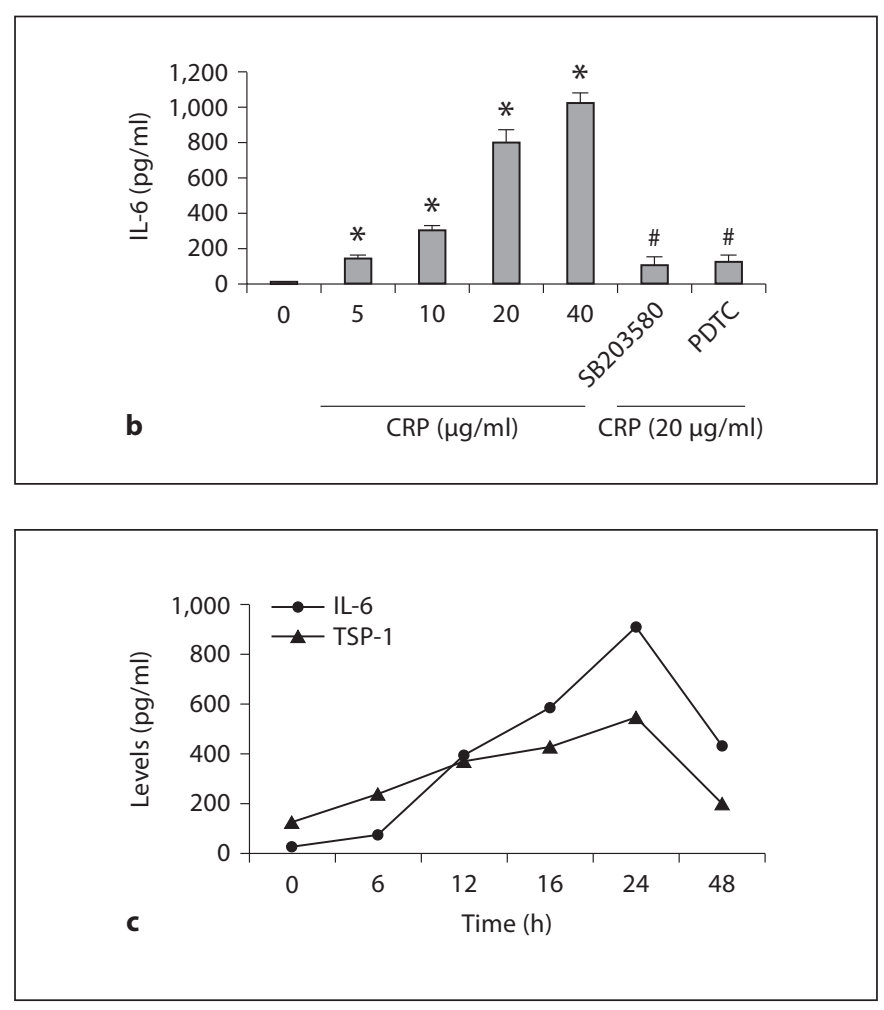

Statistical Analysis

All data are presented as means \pm SE. An unpaired Student's $t$ test was used for comparison between the treated and control groups. Additionally, ANOVA with posthoc analysis was used to compare multiple groups (SPSS 11.0). $\mathrm{p}<0.05$ was considered statistically significant.

\section{Results}

Dose- and Time-Dependent Effect of CRP on TSP-1

and IL-6 Release in HK-2 Cells

The level of TSP-1 in supernatants of HK-2 cells was $122 \pm 38 \mathrm{pg} / \mathrm{ml}$ in the absence of CRP, but increased in a dose-dependent manner as cells were stimulated by CRP (at a concentration of $5 \mu \mathrm{g} / \mathrm{ml}$, the level of TSP- 1 was $273 \pm 47$ vs. $122 \pm 38 \mathrm{pg} / \mathrm{ml}, \mathrm{p}<0.05$ ) (fig. 1a). IL-6 was rarely detected in the cultured medium in the absence of CRP $(12 \pm 4 \mathrm{pg} / \mathrm{ml})$; at a concentration of $5 \mu \mathrm{g} / \mathrm{ml}$, however, CRP triggered a marked increase in IL- 6 levels (152 \pm 13 vs. $12 \pm 4 \mathrm{pg} / \mathrm{ml}, \mathrm{p}<0.001$ ), which was significantly upregulated at concentrations of CRP $\geq 20 \mu \mathrm{g} / \mathrm{ml}$ (806 $\pm 72 \mathrm{pg} / \mathrm{ml}$ ) (fig. 1b).

We evaluated the time-course effects of CRP stimulation on IL- 6 and TSP-1 release. IL- 6 and TSP- 1 were detected in the culture medium after $6 \mathrm{~h}$ and continued to 
Table 1. ELISA for TGF- $\beta_{1}$ induced by CRP in HK-2 cells $(n=3)$

\begin{tabular}{|c|c|c|c|c|}
\hline & \multirow[t]{2}{*}{ Control } & \multicolumn{3}{|c|}{ CRP $(20 \mu \mathrm{g} / \mathrm{ml})$} \\
\hline & & CRP & IL-6 antibody $(5 \mu \mathrm{M})$ & TSP-1 antibody $(5 \mu \mathrm{M})$ \\
\hline TGF- $\beta_{1}, \mathrm{pg} / \mathrm{ml}$ & $56 \pm 12$ & $398 \pm 65^{*}$ & $378 \pm 71^{*}$ & $369 \pm 56^{*}$ \\
\hline \multicolumn{5}{|c|}{$\begin{array}{l}\text { The cells were preincubated with IL- } 6(5 \mu \mathrm{M}) \text { or TSP- } 1 \text { antibody }(5 \mu \mathrm{M}) \text { and then stimulated by CRP }(20 \mu \mathrm{g} / \\
) \text {. The results show that the levels of TGF- } \beta_{1} \text { are not influenced by these two antibodies. Our results sup- } \\
\text { rted the hypothesis that the role of CRP is direct. }\end{array}$} \\
\hline
\end{tabular}

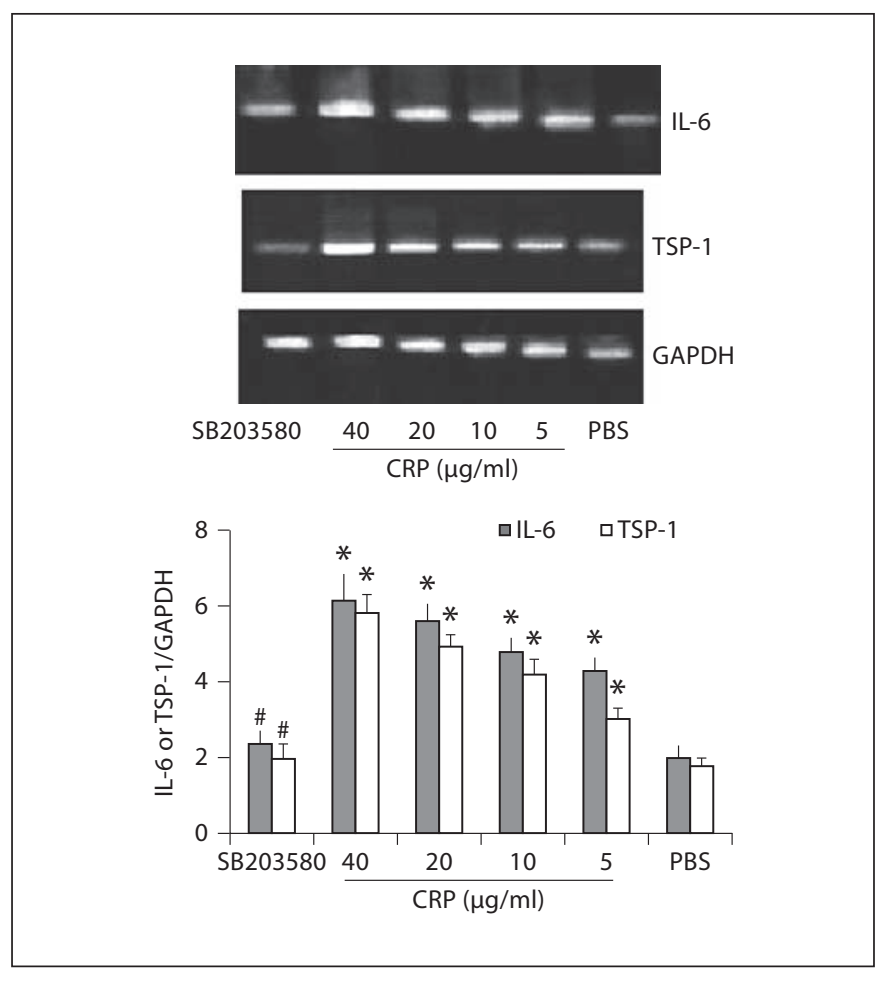

Fig. 2. Dose-dependent effect of CRP on TSP-1 and IL- 6 mRNA expression in HK-2 cells as detected via RT-PCR. ${ }^{*} \mathrm{p}<0.01$ versus the negative control group; ${ }^{\#} \mathrm{p}<0.01$ versus the CRP $(20 \mu \mathrm{g} / \mathrm{ml})$ group.

increase up to $24 \mathrm{~h}$ in response to $20 \mu \mathrm{g} / \mathrm{ml} \mathrm{CRP} \mathrm{treat-}$ ment (fig. 1c).

We also evaluated the role of the activation of p38MAPK in cytokines release by examining whether a specific inhibitor of p38MAPK (SB203580) could suppress the CRP-induced inflammatory response by HK-2 cells. Cells were treated with SB203580 (5 $\mu \mathrm{M})$ for $60 \mathrm{~min}$ prior to CRP stimulation and were then left in culture until they were harvested $24 \mathrm{~h}$ poststimulation. We found that SB203580 significantly suppressed CRP-induced IL- 6 and TSP-1 release $(p<0.05)$ (fig. 1a, b).

We also evaluated the role of the activation of NF- $\mathrm{KB}$ in cytokine release by examining whether a specific inhibitor of NF-кB (PDTC) could suppress the CRP-induced inflammatory response by HK-2 cells. Cells were treated with PDTC $(50 \mu \mathrm{M})$ for $60 \mathrm{~min}$ prior to CRP stimulation and were then left in culture until they were harvested $24 \mathrm{~h}$ poststimulation. We found that NF- $\mathrm{\kappa B}$ significantly suppressed CRP-induced IL- 6 and TSP-1 release $(\mathrm{p}<0.05)$ (fig. 1a, b).

\section{CRP Significantly Induced TGF- $\beta_{1}$ Directly in \\ HK-2 Cells}

TGF- $\beta_{1}$ expression was detected through ELISA. The levels of TGF- $\beta_{1}$ among the three groups (group 1, CRP stimulation alone; group 2, CRP with IL-6 antibody; group 3, CRP with TSP-1 antibody) were higher compared with the control group $(56 \pm 12 \mathrm{pg} / \mathrm{ml}$ ) (table 1). Although the cells were preincubated with IL- 6 or TSP-1 antibody, the levels of TGF- $\beta_{1}$ were still as high as in the CRP group $(378 \pm 71,369 \pm 56$, vs. $398 \pm 65 \mathrm{pg} / \mathrm{ml}$, respectively, $\mathrm{p}>0.05)$, there are no significant differences among those three groups, which indicated that the role of CRP on HK-2 cells is direct and not through the IL-6 or TSP-1 pathways (table 1).

\section{CRP Significantly Induced IL-6 and TSP-1 mRNA \\ Expression in HK-2 Cells}

At a concentration of as low as $5 \mu \mathrm{g} / \mathrm{ml}$, CRP induced the expression of IL- 6 and TSP-1 mRNA in HK-2 cells. The increase of mRNA expression was significant in comparison to the negative control group $(\mathrm{p}<0.05)$ (fig. 2) and proved to be dose-dependent. This effect was inhibited by preincubation of the cells with the p38MAPK-specific inhibitor SB203580 (5 $\mu \mathrm{M})$ for $60 \mathrm{~min}$ 
Fig. 3. Effect of CRP on NF- $\kappa$ B activity in HK-2 cells as determined by EMSA. Cells were incubated with PBS as control (a), and different doses of CRP (5, 10, 20 and $40 \mu \mathrm{g} / \mathrm{ml})$. b The cells were preincubated by SB203580 $(5 \mu \mathrm{M})$ or PDTC $(50 \mu \mathrm{M})$ for $2 \mathrm{~h}$ and then stimulated by CRP $(20 \mu \mathrm{g} /$ $\mathrm{ml}) .{ }^{*} \mathrm{p}<0.01$ versus group 1 (the negative control group); ${ }^{\#} \mathrm{p}<0.01$ versus the CRP $(20 \mu \mathrm{g} / \mathrm{ml})$ group $(\mathrm{n}=3)$.

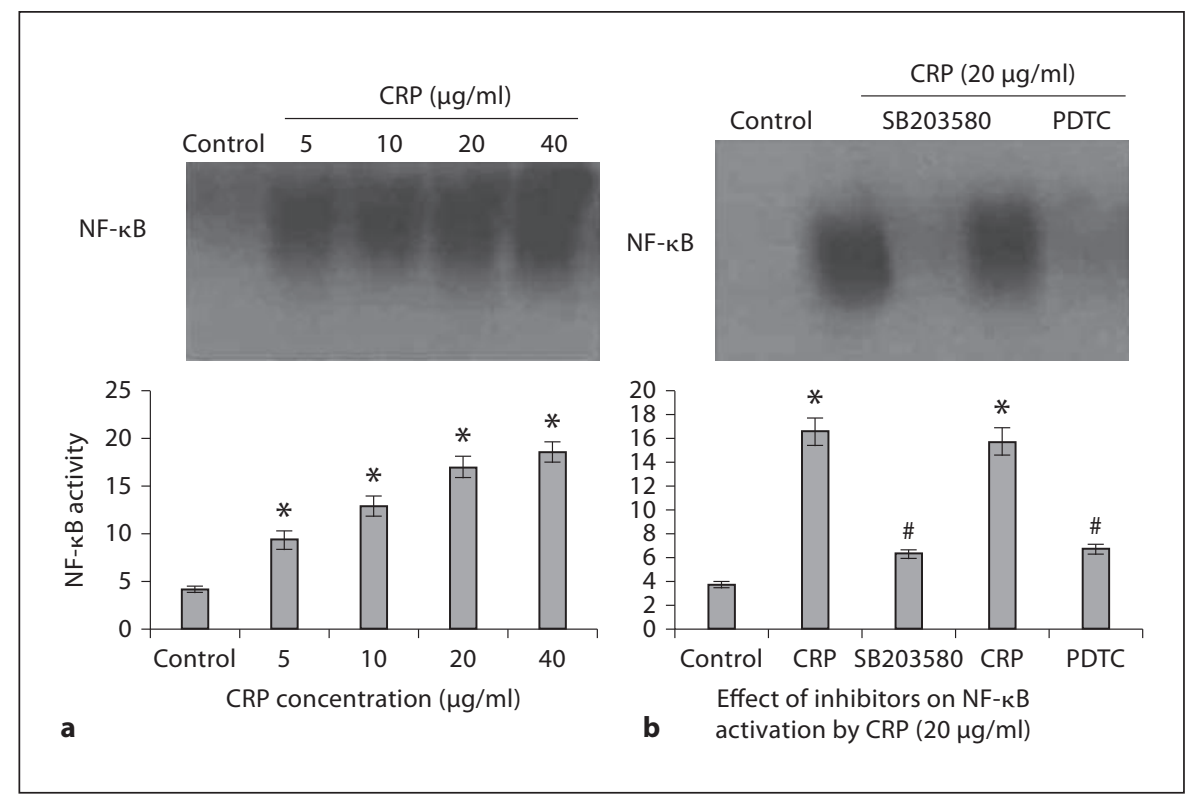

prior to CRP stimulation, which indicates that p38 was involved in the inflammatory response induced by CRP (fig. 2).

CRP Triggered the Activation of NF- $\kappa$ B in HK-2 Cells

We examined whether CRP stimulates the activation of NF- $\kappa \mathrm{B}$ in HK-2 cells via EMSA. CRP stimulation caused a marked activation of NF- $\kappa \mathrm{B}$ in a dose-dependent manner in HK-2 cells (fig. 3a). When SB203580 was added, the activation of NF- $\mathrm{KB}$ decreased significantly compared to the CRP $(20 \mu \mathrm{g} / \mathrm{ml})$ group $(\mathrm{p}<0.05)$. The similar effect of CRP on activation was inhibited by PDTC (fig. 3b). These results suggest that the CRP-induced cytokine release may be induced by the activation of NF-KB.

\section{Involvement of p38MAPK in CRP-Induced TSP-1 and \\ IL-6 Release}

Recent studies have demonstrated that CRP activates MAPKs through the Fc $\gamma$ receptor (Fc $\gamma \mathrm{R})$ [20]. We examined whether CRP stimulates the activation of MAPKs in HK-2 cells via Western blot analysis. $\beta$-Actin was used as a loading control in these assays. CRP stimulation caused a marked activation of $\mathrm{p} 38 \mathrm{MAPK}$ in HK-2 cells in a dosedependent manner (fig. 4a). SB203580 inhibited the activation of p38MAPK compared to the CRP $(20 \mu \mathrm{g} / \mathrm{ml})$ group ( $\mathrm{p}<0.05)$. These results indicate the possibility that CRP-induced cytokine release may depend, at least in part, on the phosphorylation of p38MAPK (fig. $4 \mathrm{~b}$ ).
Effect of CRP on the TSP-1, IL-6 and TGF- $\beta_{1}$ Expression of HK-2 Cells Determined via Western Blot Analysis

Cells were incubated with PBS - group CRP $(5,10,20$ and $40 \mu \mathrm{g} / \mathrm{ml})$. Also, the cells were preincubated by SB203580 $(5 \mu \mathrm{M})$ for $2 \mathrm{~h}$ or PDTC $(50 \mu \mathrm{M})$ and then stimulated with CRP $(20 \mu \mathrm{g} / \mathrm{ml})$. Western blot analysis was conducted to confirm the effect of CRP on HK-2 cells.

At a concentration of $5 \mu \mathrm{g} / \mathrm{ml}$, CRP induced the expression of IL- 6 , TSP-1 and TGF- $\beta_{1}$ protein in HK-2 cells. The increase of these protein expressions was significant separately in comparison to the negative control group $(\mathrm{p}<0.05)$ (fig. 5) and proved to be dose-dependent. These effects were inhibited by preincubation of the cells with the p38MAPK-specific inhibitor SB203580 $(5 \mu \mathrm{M})$ or PDTC $(50 \mu \mathrm{M})$ for $60 \mathrm{~min}$ prior to CRP stimulation, which indicates that $\mathrm{p} 38$ phosphorylation and NF- $\mathrm{\kappa B}$ activation were involved in the inflammatory response induced by CRP (fig. 5).

\section{Discussion}

Kidney disease is characterized by extensive tubulointerstitial fibrosis and is one of the most serious complications associated with diabetes. Tubulointerstitial fibrosis is regarded as the final common pathway in kidney disease progression as the extent and severity of tubulointerstitial fibrosis correlates most closely with declining 


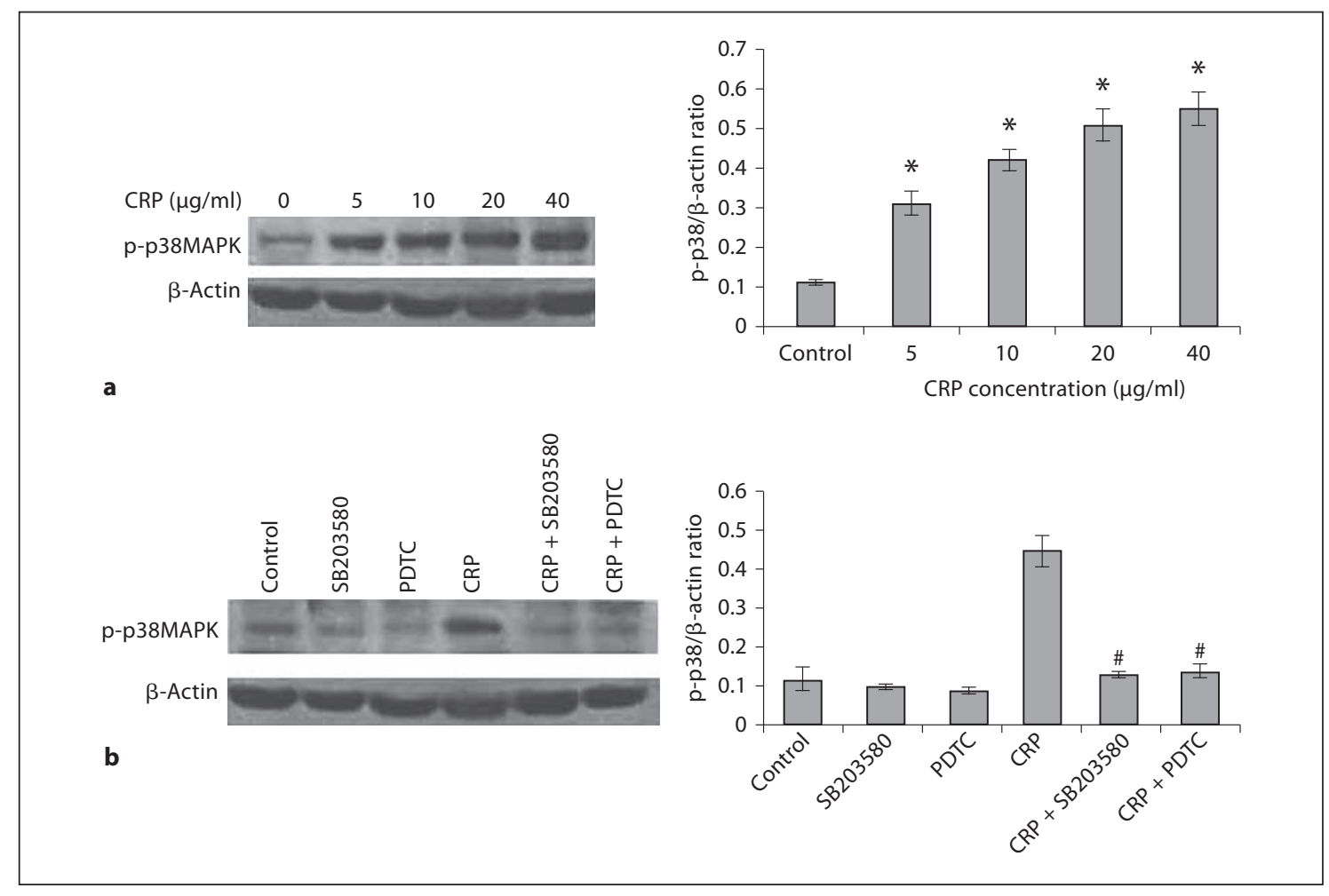

Fig. 4. Effect of CRP on the p-p38MAPK in HK-2 cells determined via Western blot analysis. a The cells were incubated with PBS as control, CRP $(5,10,20$ and $40 \mu \mathrm{g} / \mathrm{ml})$. b The cells were preincubated by SB203580 $(5 \mu \mathrm{M})$ for $2 \mathrm{~h}$ or PDTC $(50 \mu \mathrm{M})$ and then stimulated by CRP $(20 \mu \mathrm{g} / \mathrm{ml}) .{ }^{*} \mathrm{p}<0.01$ versus the control group PBS; ${ }^{\#} \mathrm{p}<$ 0.01 versus the CRP $(20 \mu \mathrm{g} / \mathrm{ml})$ group.

renal function. To provide evidence for potential links among CRP, TSP-1, IL- 6 and tubulointerstitial fibrosis in the current study, we used a human tubular cell line (HK2) to examine the cellular responses to CRP.

Previous studies have reported that serum or urinary levels of inflammatory parameters, including C-reactive protein and IL-6 [21] are elevated in patients with type 2 diabetic nephropathy [22]. TSP-1 is a multifunctional glycoprotein synthesized by many cells [23] and is involved in angiogenesis and inflammation. IL-6 plays a critical role in chronic inflammatory diseases [24].

In this study, we have demonstrated that purified CRP (sodium azide- and LPS-free) induced the active release of TSP- 1 and IL- 6 by HK-2 cells in a time- and dose-dependent manner. Purified CRP $(20 \mu \mathrm{g} / \mathrm{ml})$ induced a significant release of TSP-1 and IL- 6 by HK- 2 cells (fig. 1a, b) compared to the negative control group. CRP at concentrations of $>5 \mathrm{pg} / \mathrm{ml}$ has been shown to stimulate HK-2 cells to release the inflammatory cytokine, imply- ing that CRP can trigger the inflammatory response of HK-2 cells. The concentrations of CRP $(5-40 \mu \mathrm{g} / \mathrm{ml})$ used in the present study are equivalent to those observed in patients suffering from diabetic nephropathy, obesity and cardiovascular diseases $[25,26]$.

TSP-1 is a major endogenous activator for TGF- $\beta_{1}$, which plays a critical role in the development of renal tubulointerstitial fibrosis. In the study, the levels of TGF- $\beta_{1}$ were also detected in HK-2 cells which were preincubated with IL- 6 or TSP- 1 antibody. The levels of TGF- $\beta_{1}$ induced by CRP $(20 \mu \mathrm{g} / \mathrm{ml})$ were significantly increased compared with the control group (table 1), but adding the IL- 6 antibody or TSP-1 antibody cannot block the effect of CRP (IL- 6 antibody: $378 \pm 71$ pg/ml, TSP-1 antibody: $369 \pm 56 \mathrm{pg} / \mathrm{ml}$, vs. CRP alone: $398 \pm 65 \mathrm{pg} / \mathrm{ml}, \mathrm{p}>$ 0.05). The results indicated that the role of CRP on HK-2 cells is direct and not through the IL- 6 or TSP-1 pathways. The findings of the present study - that CRP induced HK-2 cells to release TSP-1 and IL- 6 - indicate an important pathophysiologic role for CRP in the inflam- 


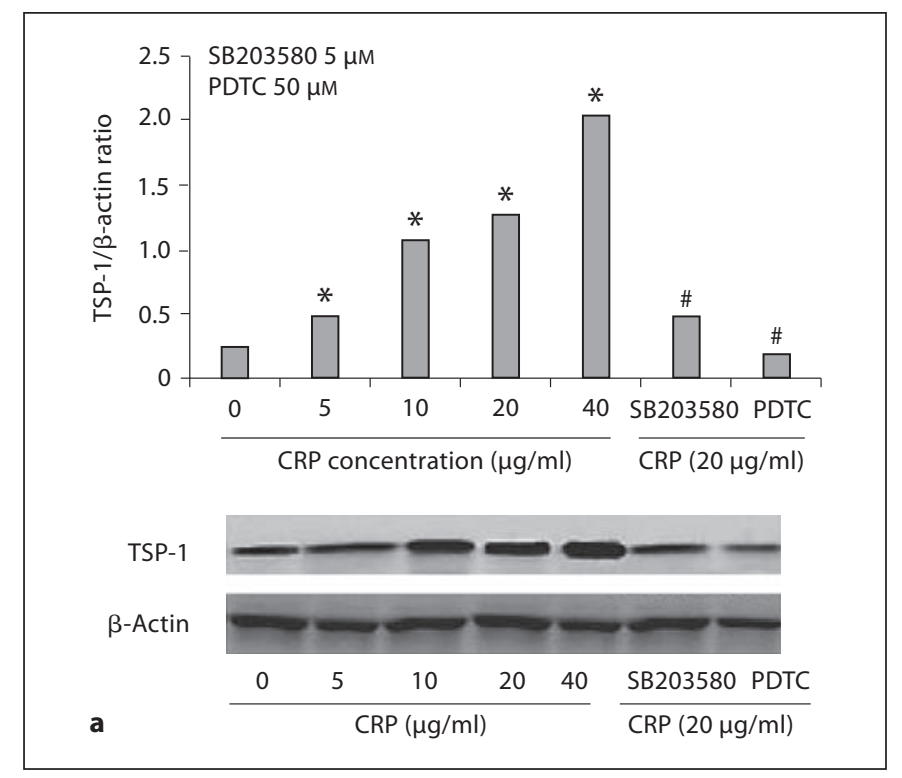

Fig. 5. Effect of CRP on TSP-1, IL- 6 and TGF- $\beta_{1}$ in HK- 2 cells determined via Western blot analysis. Cells were incubated with $\operatorname{PBS}$ and $\operatorname{CRP}(5,10,20$ and $40 \mu \mathrm{g} / \mathrm{ml})$. Also, the cells were preincubated by SB203580 $(5 \mu \mathrm{M})$ for $2 \mathrm{~h}$ or PDTC $(50 \mu \mathrm{M})$ and then stimulated by CRP $(20 \mu \mathrm{g} / \mathrm{ml})$. a Graph and gels of TSP-1 protein versus the $\beta$-actin group detected via Western blot analysis. b IL- 6 protein. c TGF- $\beta_{1}$ protein detected by Western blot analysis. ${ }^{*} \mathrm{p}<0.01$ versus the control group PBS; ${ }^{*} \mathrm{p}<0.01$ versus the CRP $(20 \mu \mathrm{g} / \mathrm{ml})$ group.

matory response of tubular epithelial cells which may lead to tubulointerstitial fibrosis.

This induction of TSP- 1 and IL- 6 release was mediated by $\mathrm{p} 38 \mathrm{MAPK}$. The effect of CRP was inhibited by the p38MAPK inhibitor SB203580 through ELISA and Western blot analysis in the study, again confirming this direct role of CRP on HK-2 cells. The p38MAPK signaling pathway plays an important role in promoting inflammatory diseases [27-29]. Activation of p38MAPK induces the production of key inflammatory mediators like TNF- $\alpha$ and IL-6 [30-32], suggesting that p38MAPK
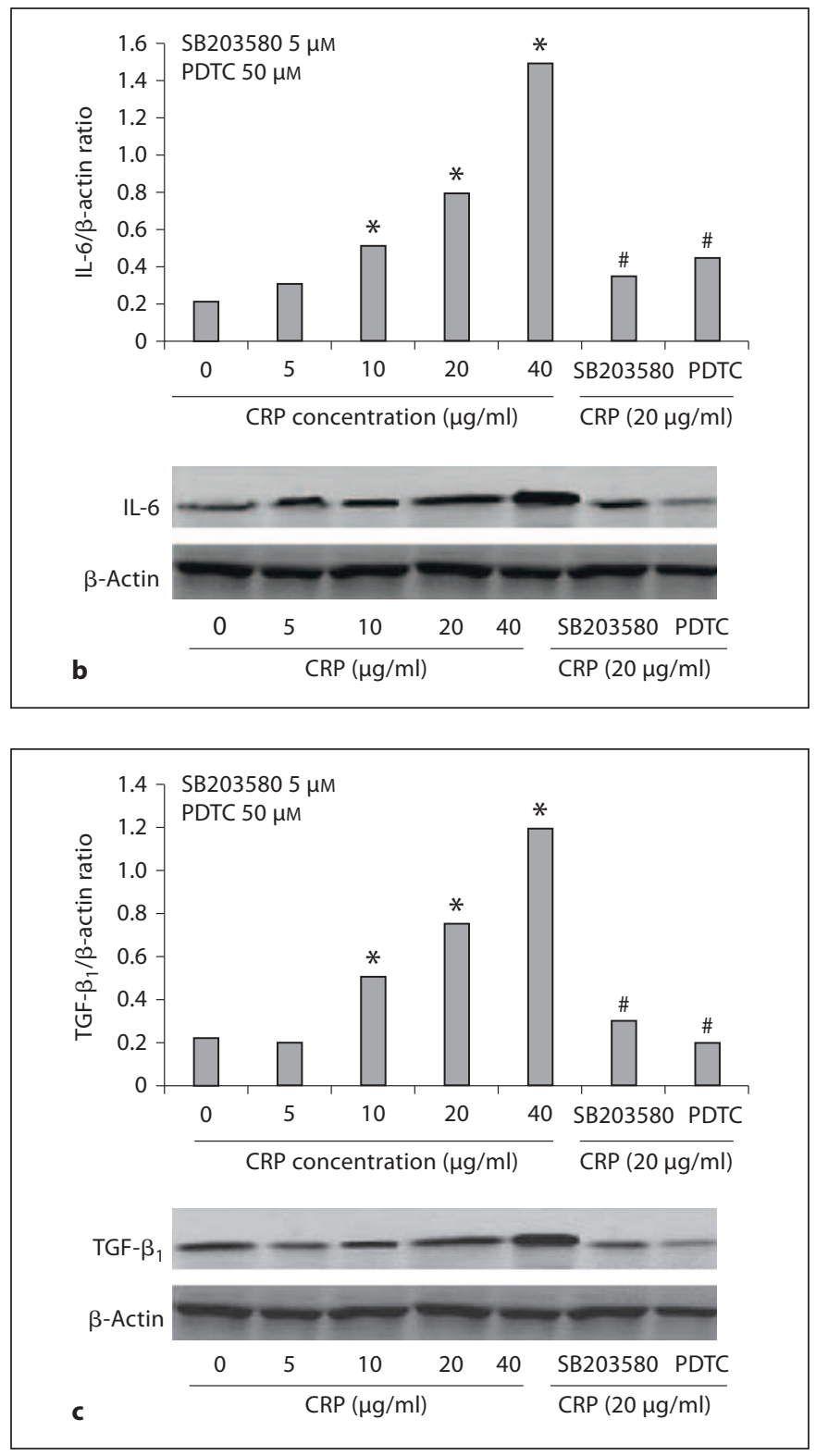

is an obvious therapeutic target for chronic inflammatory diseases.

In the current study, we observed that CRP triggered the activation of NF- $\kappa \mathrm{B}$ in a dose-dependent manner. PDTC (a metal chelator and antioxidant) can inhibit the activation of NF- $\kappa \mathrm{B}$ specifically by suppressing the release of the inhibitory subunit ІкB from the latent cytoplasmic form of NF- $\kappa \mathrm{B}$ [33]. NF- $\kappa \mathrm{B}$ played a crucial role in CRP-induced cytokine release, suggesting the involvement of NF- $\mathrm{BB}$ in the CRP-induced inflammatory response of HK-2 cells. The activation of NF- $\kappa B$ transcrip- 
tional programs that control the expression of the genes activated during inflammation in human diabetic nephropathy has recently been described [34].

IL- 6 acts on its receptor, RAGE, and activates NF- $\kappa B$ signaling to induce the expression of proinflammatory cytokines like TNF- $\alpha$. TGF- $\beta$, has been shown to stimulate vascular endothelial cells, thereby upregulating adhesion molecules like ICAM-1, and inducing granulocyte colony-stimulating factor expression and IL-8 release [35-37]. CRP induces the expression of IL- 6 in tubular cells, suggesting that CRP promotes renal tubular epithelial cell activation and dysfunction. At the same time, it is a positive feedback cycle where IL- 6 can also be transcribed by NF- $\kappa B$ induced by CRP. CRP may thus enhance the tubulointerstitium by inducing the inflammatory component of diabetic nephropathy $[38,39]$.

It has been previously demonstrated that Fc $\gamma$ RIIB underlies the actions of CRP on the vascular endothelium [40]. In kidney tubular cells, by contrast, the molecular and functional characteristics of Fc $\gamma R$ have remained unclear. Further studies are needed in order to identify the basis of the CRP-mediated processes in tubular cells. In particular, Baer et al. [41] have previously reported MAPK activation and RANTES induction by CRP in human renal distal tubular cells, and NF- $\kappa \mathrm{B}$ activation by CRP in human mesangial cells has been reported by Chang et al. [42]. More recently, p38 activation and cytokine expression by CRP were demonstrated in vascular smooth muscle cells. Our study indicated that CRP induces IL- 6 expression, which then activates NF- $\kappa \mathrm{B}$, thus enhancing the CRP actions on tubular cells, which is in contrast to previous studies [43] describing that IL-6 is not induced by CRP. Moreover, it has been demonstrated that although IL- 6 gene expression requires NF- $\mathrm{BB}$ activation, IL- 6 itself is a weak NF- $\kappa B$ inducer, and preferentially acts through the JAK/STAT pathway in different cell types. Our findings suggest that CRP plays a potentially important role in the induction of inflammatory processes, including tubulointerstitial fibrosis, by inducing the release of the key inflammatory mediators IL- 6 and TSP1 , and thus presents a potential target for the treatment of tubulointerstitial fibrosis in cases of diabetic nephropathy.

\section{Conclusion}

The interaction between the proinflammatory cytokines CRP, TSP-1 and IL-6 in renal tubular epithelial cells was previously unclear. Here, we show that CRP induces HK-2 cells to release cytokine via activation of the p38MAPK and NF- $\mathrm{KB}$ signaling pathways, suggesting that CRP plays an important role in the propagation and prolongation of inflammation of tubular epithelial cells in cases of tubulointerstitial fibrosis and diabetic nephropathy.

\section{Acknowledgments}

The study was supported by grants from the Hubei Province Scientific Research Foundation (2007AA301B36-3 and 2009CDB059), the Hubei Province Health Department Important Foundation (JX2A19) and funds from the State Key Laboratory of Freshwater Ecology and Biotechnology (2010FB12).

\section{References}

1 Lin Lu, Li Jin Pu, Xue Wei Xu, et al: Association of serum levels of glycated albumin, Creactive protein and tumor necrosis factor- $\alpha$ with the severity of coronary artery disease and renal impairment in patients with type 2 diabetes mellitus. Clin Biochem 2007;40: 810-816.

2 Busch M, Franke S, Müller A, et al: Potential cardiovascular risk factors in chronic kidney disease: AGEs, total homocysteine and metabolites, and the C-reactive protein. Kidney Int 2004;66:338-347.

>3 Peppa M, Uribarri J, Cai W, Lu M, Vlassara $\mathrm{H}$ : Glycoxidation and inflammation in renal failure patients. Am J Kidney Dis 2004;43: 690-695.

${ }^{2}$
${ }_{5}$
${ }_{6}$

4 Ridker PM, Cushman M, Stampfer MJ, Tracy $\mathrm{RP}$, Hennekens $\mathrm{CH}$ : Plasma concentration of $\mathrm{C}$-reactive protein and risk of developing peripheral vascular disease. Circulation 1998; 97:425-428.

5 Ridker PM, Hennekens CH, Buring JE, Rifai $\mathrm{N}$ : C-reactive protein and other markers of inflammation in the prediction of cardiovascular disease in women. N Engl J Med 2000; 342:836-843.

6 Biasucci LM, Liuzzo G, Buffon A, Maseri A: The variable role of inflammation in acute coronary syndromes and in restenosis. Semin Interv Cardiol 1999;4:105-110.

7 Gussekloo J, Schaap MCL, Frölich M, Blauw GJ, Westendorp RGJ: C-reactive protein is a strong but nonspecific risk factor of fatal stroke in elderly persons. Arterioscler Thromb Vasc Biol 2000;20:1047-1051.
$>8$ Kawahara K, Biswas KK, Unoshima M, et al: $\mathrm{C}$-reactive protein induces high-mobility group box-1 protein release through activation of p38MAPK in macrophage RAW264.7 cells. Cardiovasc Pathol 2008;17:129-138.

9 Ridker PM, Hennekens CH, Buring JE, Rifai $\mathrm{N}$ : C-reactive protein increases plasminogen activator inhibitor-1 expression in human endothelial cells. Thromb Res 2008;122:125133.

10 Wang H, Li J, Huang C, et al: Fluvastatin inhibits the expression of tumor necrosis factor-alpha and activation of nuclear factorkappa B in human endothelial cells stimulated by C-reactive protein. Clin Chim Acta 2005;353:53-60. 
11 Li J, Wang H, Huang C, et al: Enhanced inflammatory response of blood monocytes to C-reactive protein in patients with unstable angina. Clin Chim Acta 2005;352:127-133.

$\checkmark 12$ Jinde K, Nikolic-Paterson DJ, Huang XR, et al: Tubular phenotypic change in progressive tubulointerstitial fibrosis in human glomerulonephritis. Am J Kid Dis 2001;38:761-769.

$\checkmark 13$ Stenina OI, Krukovets I, Wang K, et al: Increased expression of thrombospondin-1 in vessel wall of diabetic Zucker rat. Circulation 2003; 107:3209-3215.

-14 Janabi M, Yamashita S, Hirano K, et al: Oxidized LDL-induced NF-kappaB activation and monocyte-derived macrophages from CD36-deficient patients. Arterioscler Thromb Vasc Biol 2000;20:1953-1960.

$\checkmark 15$ Han KH, Hong K-H, Park J-H, et al: C-reactive protein promotes monocyte chemoattractant protein-1-mediated chemotaxis through upregulating CC chemokine receptor 2 expression in human monocytes. Circulation 2004; 109:2566-2571.

16 Livak KJ, Schmittgen TD: Analysis of relative gene expression data using real-time quantitative PCR and the 2(-Delta Delta C(T)) method. Methods 2001;25:402-408.

- 17 Inoue K, Kawahara K, Biswas KK, Ando K, Mitsudo K, Nobuyoshi M, Maruyama I: HMGB1 expression by activated vascular smooth muscle cells in advanced human atherosclerosis plaques. Cardiovasc Pathol 2007;16:136-143.

-18 Yudkin JS, Kumari M, Humphries SE, Mohamed-Ali V: Inflammation, obesity, stress and coronary heart disease: is interleukin-6 the link? Atherosclerosis 2000;148:209-214.

$\checkmark 19$ Beg AA, Finco TS, Nantermet PV, Baldwin AS Jr: Tumor necrosis factor and interleukin-1 lead to phosphorylation and loss of $\kappa \mathrm{B} \alpha$ : a mechanism for NF- $\kappa \mathrm{B}$ activation. Mol Cell Biol 1993;13:3301-3310.

-20 Bang R, Marnell L, Mold C, et al: Analysis of binding sites in human $\mathrm{C}$-reactive protein for Fc\{gamma\}RI, Fc \{gamma\}RIIA, and C1q by site-directed mutagenesis. J Biol Chem 2005;280:25095-25102.

-21 Dalla Vestra M, Fioretto P: Diabetic nephropathy: renal structural studies in type 1 and type 2 diabetic patients. Int Congr Ser 2005; 1253:163-169.

-22 Fioretto P, Bruseghin M, Barzon I, Arboita M, Dalla Vestraa M: Diabetic nephropathy: an update on renal structure. Int Congr Ser 2007;1303:51-59.

$\checkmark 23$ Bonnefoy A, Moura R, Hoylaerts MF: The evolving role of thrombospondin-1 in hemostasis and vascular biology. Cell Mol Life Sci 2008,65:713-727.
24 Vickers MA, Green FR, Terry C, et al: Genotype at a promoter polymorphism of the interleukin- 6 gene is associated with baseline levels of plasma C-reactive protein. Cardiovasc Res 2002;53:1029-1034.

25 Yeh ET, Anderson HV, Pasceri V, Willerson JT: C-reactive protein: linking inflammation to cardiovascular complications. Circulation 2001;104:974-975.

26 Tomai F, Crea F, Gaspardone A, et al: Unstable angina and elevated C-reactive protein levels predict enhanced vasoreactivity of the culprit lesion. Circulation 2002;104:14711476.

27 Nishikawa M, Myoui A, Tomita T, et al: Pre vention of the onset and progression of collagen-induced arthritis in rats by the potent p38 mitogen-activated protein kinase inhibitor FR167653. Arthritis Rheum 2003;48: 2670-2681.

28 Kuldo JM, Westra J, Asgeirsdottir SA, et al Differential effects of NF-\{kappa\}B and p38 MAPK inhibitors and combinations thereof on TNF-\{alpha\}- and IL-1\{beta\}-induced proinflammatory status of endothelial cells in vitro. Am J Physiol Cell Physiol 2005;289: 1229-1239.

29 Pepys MB, Hirschfield GM, Tennent GA, et al: Targeting C-reactive protein for the treatment of cardiovascular disease. Nature 2006; 440:1217-1221.

30 Johansen C, Funding AT, Otkjaer K, et al: Protein expression of TNF-\{alpha\} in psoriatic skin is regulated at a posttranscriptional level by MAPK-activated protein kinase 2. J Immunol 2006;176:1431-1438.

31 Perlstein RS, Whitnall MH, Abrams JS, Mougey EH, Neta R: Synergistic roles of interleukin-6, interleukin-1, and tumor necrosis factor in the adrenocorticotropin response to bacterial lipopolysaccharide in vivo: synergistic roles of interleukin-6, interleukin-1, and tumor necrosis factor in the adrenocorticotropin response to bacterial lipopolysaccharide in vivo. Endocrinology 1993;132:946-952.

32 Münzel D, Lehle K, Haubner F, et al: Impact of diabetic serum on endothelial cells: An invitro-analysis of endothelial dysfunction in diabetes mellitus type 2. Biochem Biophys Res Commun 2007;362:238-244.
33 Brennan P, O’Neill LA: 2-mercaptoethanol restores the ability of nuclear factor kappa $B$ (NF kappa B) to bind DNA in nuclear extracts from interleukin 1-treated cells incubated with pyrollidine dithiocarbamate (PDTC): evidence for oxidation of glutathione in the mechanism of inhibition of NF kappa B by PDTC. Biochem J 1996;320:975981.

34 Kalinina N, Agrotis A, Antropova Y, DiVitto G, Kanellakis P, Kostolias G, et al: Increased expression of the DNA-binding cytokine IL- 6 in human atherosclerotic lesions. Arterioscler Thromb Vasc Biol 2004;24:241-247.

35 Verma S, Li SH, Badiwala MV, et al: Endothelin antagonism and interleukin- 6 inhibition attenuate the proatherogenic effects of C-reactive protein. Circulation 2002;23:18901896

-36 Thieringer R, Fenyk-Melody JE, Le Grand $\mathrm{CB}$, et al: Activation of peroxisome proliferator-activated receptor gamma does not inhibit IL-6 or TNF-alpha responses of macrophages to lipopolysaccharide in vitro or in vivo. Immunology 2000;164:1046-1054.

37 Tang D, Shi Y, Kang R, et al: Hydrogen peroxide stimulates macrophages and monocytes to actively release HMGB. J Leukoc Biol 2007;81:741-747.

>38 Argania H, Aghaeishahsavarib M, Noroozianavval $M$, et al: Effects of losartan and enalapril on high-sensitivity C-reactive protein and total antioxidant in renal transplant recipients with renin-angiotensin system polymorphisms. Transplant Proc 2008;40: 16-21.

39 Maeda S: Do inflammatory cytokine genes confer susceptibility to diabetic nephropathy? Kidney Int 2008;74:413-415.

40 Mineo C, Gormley AK, Yuhanna IS, et al: FcgammaRIIB mediates C-reactive protein inhibition of endothelial NO synthase. Circ Res 2005;97:1124-1131.

-41 Baer PC, Gauer S, Wegner B, Schubert R, Geiger H: C-reactive protein induced activation of MAP-K and RANTES in human renal distal tubular epithelial cells in vitro. Clin Nephrol 2006;66:177-183.

42 Chang JW, Kim CS, Kim SB, et al: C-reactive protein induces NF-kappaB activation through intracellular calcium and ROS in human mesangial cells. Nephron Exp Nephrol 2005;101:e165-e172.

43 Patel DN, King CA, Bailey SR, et al: Interleukin-17 stimulates C-reactive protein expression in hepatocytes and smooth muscle cells via p38 MAPK and ERK1/2-dependent NF$\kappa \mathrm{B}$ and C/EBPß. J Biol Chem 2007;282: 27229-27238. 